\title{
Project Knowledge of 4-H Members Who Participated in the Equine Skillathon at the West Virginia State Fair
}

\author{
Kolby Denae Wyant \\ West Virginia University
}

Follow this and additional works at: https://researchrepository.wvu.edu/etd

\section{Recommended Citation}

Wyant, Kolby Denae, "Project Knowledge of 4-H Members Who Participated in the Equine Skillathon at the West Virginia State Fair" (2013). Graduate Theses, Dissertations, and Problem Reports. 349.

https://researchrepository.wvu.edu/etd/349

This Thesis is protected by copyright and/or related rights. It has been brought to you by the The Research Repository @ WVU with permission from the rights-holder(s). You are free to use this Thesis in any way that is permitted by the copyright and related rights legislation that applies to your use. For other uses you must obtain permission from the rights-holder(s) directly, unless additional rights are indicated by a Creative Commons license in the record and/ or on the work itself. This Thesis has been accepted for inclusion in WVU Graduate Theses, Dissertations, and Problem Reports collection by an authorized administrator of The Research Repository @ WVU. For more information, please contact researchrepository@mail.wvu.edu. 
Project Knowledge of 4-H Members Who Participated in the Equine Skillathon at the West Virginia State Fair

\title{
Kolby Denae Wyant
}

Thesis submitted to the

Davis College of Agriculture, Natural Resources and Design

at West Virginia University

in partial fulfillment of the requirements

for the degree of

\author{
Master of Science \\ in \\ Agricultural and Extension Education
}

Deborah A. Boone, Ph.D., Chair

Harry N. Boone, Jr., Ph.D.

Jean M. Woloshuk, Ed.D.

Division of Resource Management

Morgantown, West Virginia

2013

Keywords: 4-H, youth, knowledge, horse, equine 


\begin{abstract}
Project Knowledge of 4-H Members Who Participated in the Equine Skillathon at the West Virginia State Fair
\end{abstract}

Kolby Denae Wyant

An Equine Skillathon is conducted annually at the West Virginia State Fair in Department F that is open to 4-H and FFA members. At the 2012 West Virginia State Fair, a descriptive research study was done utilizing the Equine Skillathon as the method of instrumentation. The study was conducted to assess the fundamental equine knowledge of junior and senior 4-H members who participated in the 2012 State Fair Equine Skillathon in the five categories of breed identification, conformation, body and hoof parts, as well as feed identification. The data was collected from the participating 4-H members' score sheets and used for the analysis. There were no differences in the scores for junior and senior 4-H members on breed identification, hoof parts, or feed identification. Senior members did score higher on conformation and body parts. Body parts had the lowest scores of all sections for both groups. Senior members scored less than $50 \%$ on the equine knowledge test. There was an association between the participants' years of participation in the 4-H Horse project, a County 4-H Horse Show, the State Fair Junior Horse and Pony Show, and the State Fair Equine Skillathon and their fundamental equine knowledge. Although a majority of the participants had participated in various horse shows and events, their equine knowledge was limited. 


\section{DEDICATION}

First and foremost, I want to dedicate this thesis to my parents- Mark T. and

Deborah A. Wyant. Without their support throughout my years of college, this would not be possible. Thank you for everything, and I love you!

Secondly, I want to dedicate this thesis to my grandparents- Gearld L. and Deloris A. Perry. Without them, I do not know if any of this would have been possible. I will never be able to thank them enough for what they have helped me accomplish. Thank you for everything, and I love you!

Last but certainly not least, I want to dedicate this thesis to my fiancé (soon to be husband) Robert L. Scarberry. Without Robert, I probably would not have even gone through with graduate school. He pushed me to follow the path I always said I was going to take, even when I had reached a point that I had wanted to just stop and quit. Thank you for everything, and I love you! 


\section{ACKNOWLEDGEMENTS}

To my parents, thank you:

\section{Mark T. and Deborah A. Wyant}

I do not know where I would be without you. Thank you, and I love you!

To my grandparents, thank you:

\section{Gearld L. and Deloris A. Perry}

I do not know where I would be without you. Thank you, and I love you!

To my fiancé (soon to be husband), thank you:

\section{Robert L. Scarberry}

Not only are you the love of my life, but I know I would probably not be writing this thesis if it wasn't for your encouragement and support. Thank you, and I love you!

To my advisory committee, thank you:

\section{Deborah A. Boone, Ph.D., Chair}

\section{Harry N. Boone, Jr., Ph.D.}

Jean M. Woloshuk, Ed.D.

This thesis would not be possible without all of your guidance and assistance. I am forever grateful to you; there is no way I could have done this alone!

To all other family and friends, thank you for always being supportive of me and encouraging me to continue my education. 


\section{TABLE OF CONTENTS}

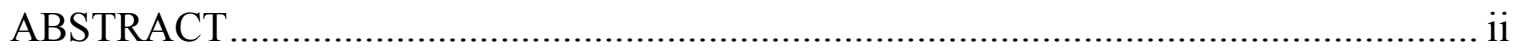

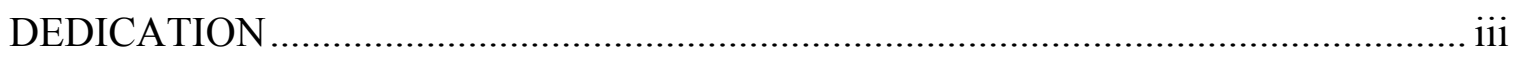

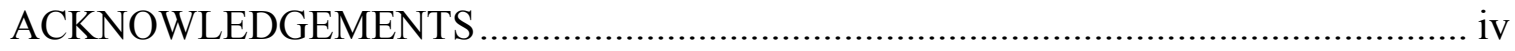

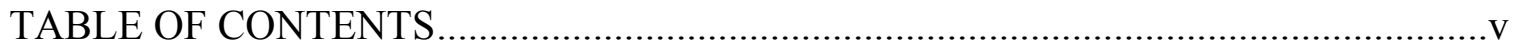

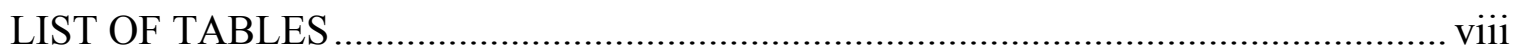

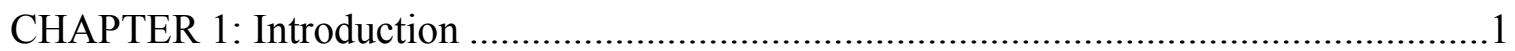

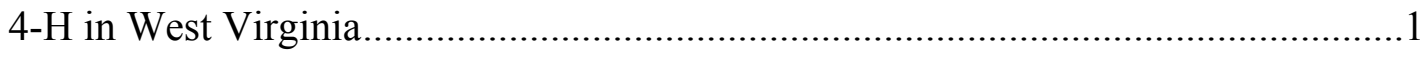

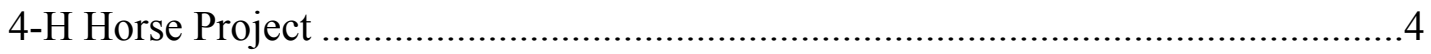

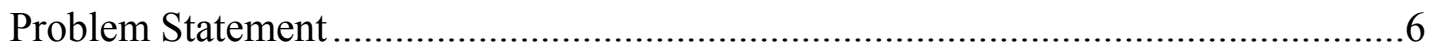

Purpose of the Study .........................................................................................

Research Questions and Hypotheses ............................................................

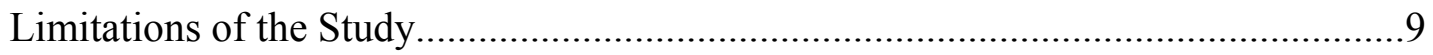

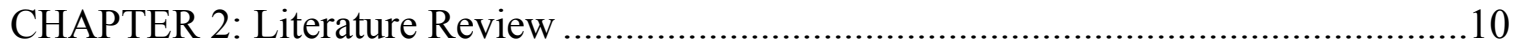

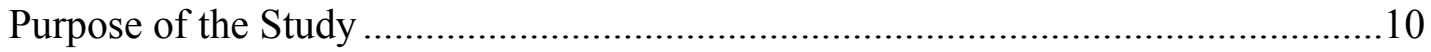

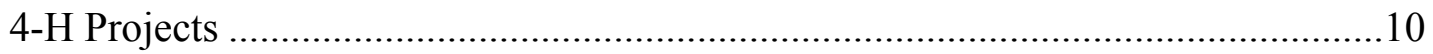

4-H Participation and Life Skills Development................................................. 13

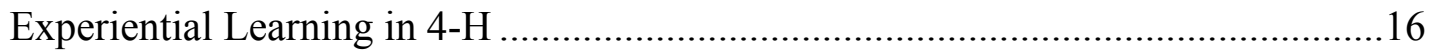

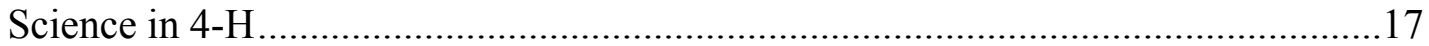

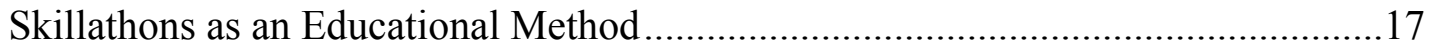


4-H Horse Program Studies

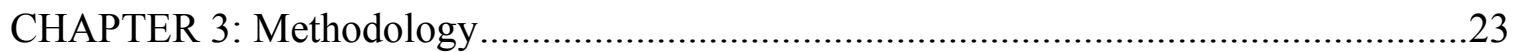

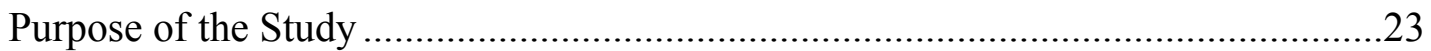

Research Questions and Hypotheses ...............................................................23

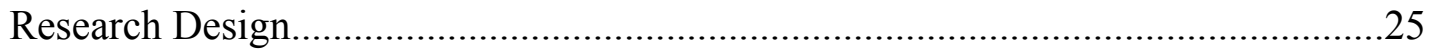

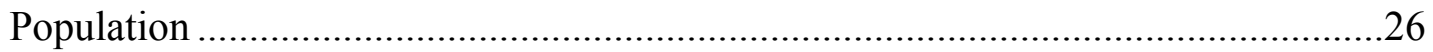

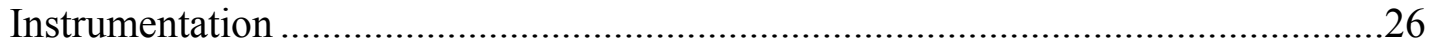

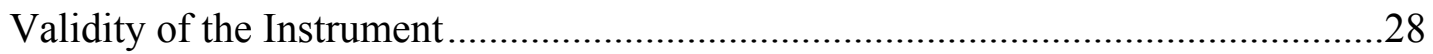

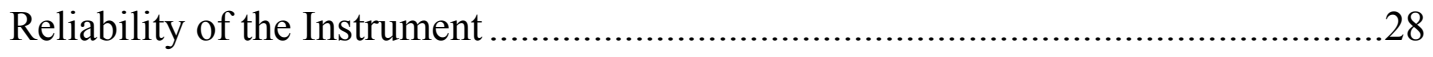

Data Collection Procedures................................................................................29

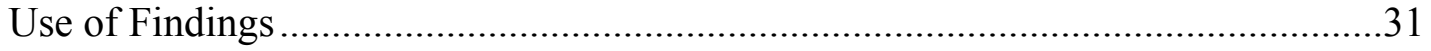

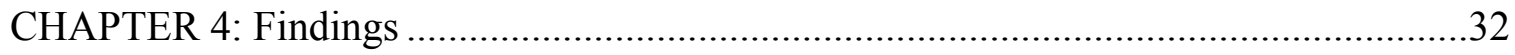

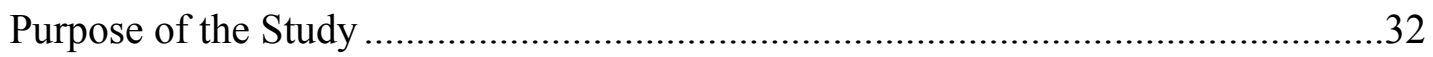

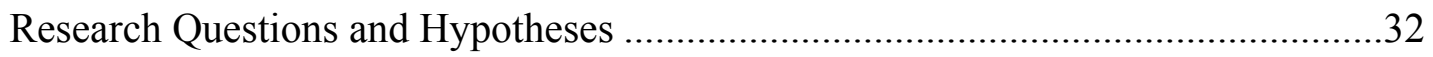

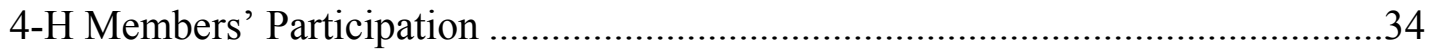

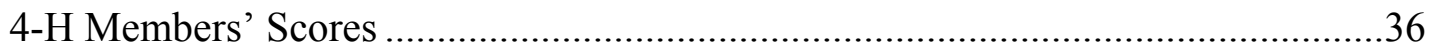

4-H Members' Event Participation ............................................................... 38

Senior Member Multiple Choice Questions ..................................................40

4-H Members' Composite Scores .....................................................................41 
Associations between Years of Participation and Fundamental Equine

Knowledge

CHAPTER 5: Summary, Conclusions, and Recommendations

Purpose of the Study

Research Questions and Hypotheses

Summary

Conclusions .53

Recommendations. .54

REFERENCES .55

APPENDICES .61

APPENDIX A: 2012 State 4-H Equine Skillathon..... .62

APPENDIX B: 2012 State 4-H Equine Skillathon Key 64

APPENDIX C: 2012 State 4-H Equine Junior Skillathon .66

VITA .68 


\section{LIST OF TABLES}

$\begin{array}{lll}\text { Table Title } & \text { Page }\end{array}$

1 4-H Status of 2012 State Fair Equine Skillathon Participants .35

3 Scores Earned in Each Category of the 2012 State Fair Equine

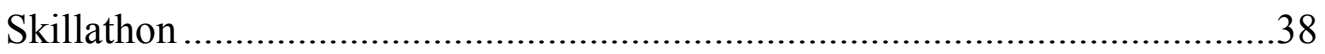

4 Years of Participation in Various Events

6 Composite Results of the 2012 State Fair Equine Skillathon

9 Association Between Years of Participation in the 4-H Horse Project and Fundamental Equine Knowledge

10 Association Between Years of Participation in a County 4-H Horse

Show and Fundamental Equine Knowledge.....

11 Association Between Years of Participation in the State Fair Junior

Horse and Pony Show and Fundamental Equine Knowledge

Association Between Years of Participation in the State Fair Equine

Skillathon and Fundamental Equine Knowledge. 


\section{CHAPTER 1}

\section{Introduction}

4-H is the largest youth development organization in the United States (National 4-H Council, 2012). It can be said that 4-H has unparalleled reach and scope. With approximately 540,000 volunteers, 3,500 professionals, and more than 60 million alumni, 4-H supports young people from elementary school through high school with programs designed to shape future leaders and innovators (National 4-H Council, 2012).

More than six million youth in urban, suburban, and rural farming communities are involved in 4-H (National 4-H Council, 2012). In most states, youth can join 4-H if they are between the ages of eight and 18 years old (National 4-H Council, 2012). Some areas have special age-appropriate programs designed especially for younger kids, such as the "Cloverbud" program (National 4-H Council, 2012).

As the youth development program associated with the nation's land-grant universities and the Extension System, 4-H fosters an innovative, "Learn by Doing" approach (National 4-H Council, 2012). The 4-H Study of Positive Youth Development, a longitudinal study conducted by the Institute for Applied Research in Youth Development at Tufts University, shows youth engaged with 4-H are nearly two times more likely to get better grades in school, nearly two times more likely to plan to go to college, $41 \%$ less likely to engage in risky behaviors, and $25 \%$ more likely to positively contribute to their families and communities (National 4-H Council, 2012).

\section{4-H in West Virginia}

Projects are a major curriculum emphasis in 4-H. From 1912 to today, projects have diversified from the basic corn, pigs, tomatoes, flowers, sewing, and canning topics 
to more than 100 project areas (Woloshuk, Brown, \& Wagaman, 1999). In the West Virginia 4-H program, a project is defined as a method for teaching girls and boys many new skills. A variety of topics are offered. Members share in setting goals, making decisions, learning, and evaluation (Woloshuk, et al., 1999).

Though 4-H has expanded its educational initiatives beyond agriculture and farm based educational projects, agricultural science projects, and programming still remain a mainstream 4-H activity and provide a focus for county fairs and 4-H competitions. There is a programmatic need for evidence that these agricultural science projects and activities develop project and life skills in the youth participants (McKee, Talbert, \& Barkman, 2002; Mincemoyer \& Corbin, 2001; Schlink, 2000).

Experiential learning is not a new idea to the realm of education. Numerous individuals have proposed learning models that resembled experiential learning. Extension 4-H faculty and county-based academic staff have been developing and promoting experiential learning for use in 4-H for several decades (McCarther, Shields, \& Zurcher, 1987; Horton \& Konen, 1997; Horton, Hutchison, Barkman, Machtmes, \& Myers, 1999).

To address increased demand for science and technology professionals, 4- $\mathrm{H}$ is also working diligently to reach young people with science programs. 4-H Science programs are hands-on learning experiences, and the approach is comprehensive and holistic including agriculture, and animal sciences, while youth are learning about highly relevant complex systems and issues in their communities today.

4-H and FFA members in West Virginia have the opportunity to participate in an equine skillathon, as part of Department F: State 4-H and FFA Junior Livestock Show at 
the West Virginia State Fair. A skillathon is a "knowledge assessment" that involves fun, hands-on educational activities, where experiential learning, science, and life-skill development can intertwine. According to Blalock and Strieter (2007), a well-designed skillathon provides participants with opportunities to increase subject matter knowledge and skills. Participants in a skillathon rotate through a series of stations that test their knowledge and abilities. Participation in the skillathon at the West Virginia State Fair is voluntary (The State Fair of West Virginia Exhibitors' Guide, 2012).

In Department F: State 4-H and FFA Junior Livestock Show at the West Virginia State Fair, participants in the Junior Division must be nine years old or in the third grade during the current 4-H year, which is from October 1 to September 30, and may not have reached their 14 year old birthday on or before January 1. In the Senior Division, participants must be at least 14 years old on or before January 1, and may not have reached their 21 year old birthday on or before January 1 (The State Fair of West Virginia Exhibitors’ Guide, 2012).

Most 4-H members in West Virginia have the opportunity to exhibit a project at an annual local fair, county fair, or the West Virginia State Fair. The animal science projects available to West Virginia 4-H members are: Beef Heifer/Cow, Market Steer, Feeder Calf, Market Hog, Purebred Swine, Market Lamb, Breeding Sheep, Dairy Goat, Market Goat, Dairy Cattle, Horse, Market Rabbit, Poultry, Veterinary Science, Dog, Pet Pals and Cat (West Virginia Guide to 4-H Projects, 2012). Projects which can be exhibited in Department F at the West Virginia State Fair Junior Livestock Division include: Junior feeder steers (feeder calves), Junior Beef Heifers, Purebred and Commercial Heifers, Market Steers, Dairy Cattle, Market Lambs, Purebred Sheep, 
Market Swine, Purebred Swine, Market Goats, and Horses (The State Fair of West Virginia Exhibitors’ Guide, 2012).

\section{4-H Horse Project}

The 4-H Horse project is for individuals who want to learn about the value of owning, caring for, and exhibiting their horse(s). According to Plaugher, Workman, Linger, Schuller, and Woloshuk (2006):

Some of the important objectives to achieve from this project are to: develop an understanding of and appreciation for the humane treatment of animals, acquire safety skills necessary to prevent injury to persons and animals, develop and learn horsemanship skills, explore horses as a business- breeding, training, raising, and riding enterprise, develop skills in management by owning a horse or pony and being responsible for its care, appreciate riding as a recreational activity, and develop sportsmanship, cooperation, decision-making ability, public speaking ability, and other life skills. (inside front cover)

4-H members gain knowledge about equine primarily through the five project curriculum books, record guides, and working with 4-H leaders. According to the West Virginia Guide to 4-H Projects (2012), the 4-H Horse project has five levels, with each level providing activities for three years. 4-H members must complete seven horse achievement program activities each year, complete each level within three years, and participate in the required number of project learning experiences each year. If enrolled with an animal, the youth need to complete the 4-H Horse Record Guide to accompany the project level. 
The current project books include: Giddy Up and Go (Horse 1), which covers horse behavior, terms, breed identification, body parts, selection, grooming, saddling and bridling, and safety and equipment. Head, Heart, and Hooves (Horse 2), which covers more about acquiring and raising a horse, nutrition and care, teeth and bones, and judging, including giving oral reasons. Stables Relationships (Horse 3), which has the 4-H member exploring horse reproduction, diseases and health care, pasture management, providing appropriate shelter, and building a financial plan. Riding the Range (Horse 4), in which 4-H members learn nine basic riding skills and 10 horsemanship skills, training techniques, trail riding and selection, and use of tack; and Jumping to New Heights (Horse 5), which has more advanced riding skills, the Quarter System, horse showmanship, ethics, and leadership. A Horse Project Helper's Guide is available to assist 4-H group leaders and members' parents in helping the 4-H members complete their West Virginia 4-H Horse Program projects each year, in addition to various supplemental materials.

It is important that 4-H members learn fundamental equine knowledge so they are better prepared to work with a horse. A study conducted by Beck, Rayfield, Flowers, and Jones (2010) showed that 4-H members in North Carolina did not follow good basic ground safety practices with horses. As an equestrian, the number one priority should be to have basic knowledge of the horse in order to maintain a safe and healthy animal; thus, keeping the 4-H members safe.

Projects are a major curriculum emphasis in 4-H. In the West Virginia 4-H program, a project is defined as a method for teaching girls and boys many new skills. Project completion is defined by a three-fold process entailing a project exhibit as 
specified by a particular project, a completed project booklet, and a 4-H activity record. (Woloshuk, Brown, \& Wagaman, 1999). Each year, many questions arise regarding project selection, content, usage, costs, completion, and how this educational methodology for learning is beneficial to the youth participants. Demonstrating positive results has been difficult and reported advantages to participation are often more suggestive than definitive (Woloshuk, et al., 1999).

Though 4-H has expanded its educational initiatives beyond agriculture and farm based educational projects; agricultural science projects and programming still remain a mainstream 4-H activity and provide a focus for county fairs and 4-H competitions. Extension personnel, parents, and youth often credit agricultural science projects and programming with teaching life and project skills. Stakeholders, legislators, and administrators want verifiable evidence of impacts, success stories, and testimonials that are no longer sufficient. There is a programmatic need for evidence that agricultural science projects and activities develop project knowledge and life skills in the youth participants (McKee, Talbert, \& Barkman, 2002; Mincemoyer \& Corbin, 2001; Schlink, 2000).

\section{Problem Statement}

What is the knowledge level of West Virginia 4-H members' with regard to fundamental equine knowledge? Do the 4-H members who participated in the Equine Skillathon at the 2012 West Virginia State Fair possess fundamental equine knowledge?

\section{Purpose of the Study}

This study was designed to determine West Virginia 4-H Horse program participants' equine knowledge. The focus of this study was the fundamental equine 
knowledge specifically related to horse breed identification, conformation, body and hoof parts, as well as feed identification that West Virginia junior and senior 4-H members who participated in the Equine Skillathon at the 2012 West Virginia State Fair possessed.

\section{Research Questions and Hypotheses}

The objectives of the study are reflected in the following research questions:

1. What are the 2012 State Fair Equine Skillathon participants' knowledge of breeds of horses?

2. What are the 2012 State Fair Equine Skillathon participants' knowledge of the body parts of a horse?

3. What are the 2012 State Fair Equine Skillathon participants' knowledge of conformational faults and abnormalities?

4. What are the 2012 State Fair Equine Skillathon participants' knowledge of the parts of a horse's hoof?

5. What are the 2012 State Fair Equine Skillathon participants' knowledge of feed types and ingredients?

6. Is there an association between members' years of 4-H participation and their fundamental equine knowledge?

7. Is there an association between members' years of participation in the 4-H Horse Project and their fundamental equine knowledge?

8. Is there an association between a 4-H member having shown at a County 4-H Horse Show and their fundamental equine knowledge? 
9. Is there an association between a 4-H member having participated in the Equine Skillathon at the West Virginia State Fair and their fundamental equine knowledge?

The following hypotheses were used:

Null 1: There was no association between the 2012 State Fair Equine Skillathon participants' years of participation in 4-H and their fundamental equine knowledge. Research 1: There was an association between the 2012 State Fair Equine Skillathon participants' years of participation in 4-H and their fundamental equine knowledge. Null 2: There was no association between the 2012 State Fair Equine Skillathon participants' years of participation in the 4-H Horse project and their fundamental equine knowledge.

Research 2: There was an association between the 2012 State Fair Equine Skillathon participants' years of participation in the 4-H Horse project and their fundamental equine knowledge.

Null 3: There was no association between the 2012 State Fair Equine Skillathon participants' years of participation in a County 4-H Horse Show and their fundamental equine knowledge.

Research 3: There was an association between the 2012 State Fair Equine Skillathon participants' years of participation in a County 4-H Horse Show and their fundamental equine knowledge.

Null 4: There was no association between the 2012 State Fair Equine Skillathon participants' years of participation in the State Fair Junior Horse and Pony Show and their fundamental equine knowledge. 
Research 4: There was an association between the 2012 State Fair Equine Skillathon participants' years of participation in the State Fair Junior Horse and Pony Show and their fundamental equine knowledge.

Null 5: There was no association between the 2012 State Fair Equine Skillathon participants' years of participation in the State Fair Equine Skillathon and their fundamental equine knowledge.

Research 5: There was an association between the 2012 State Equine Skillathon participants' years of participation in the State Fair Equine Skillathon and their fundamental equine knowledge.

\section{Limitations of the Study}

The primary limitation of this study was that the entire target population was not accessible. The accessible sample consisted of all 4-H members who took part in the Equine Skillathon at the 2012 West Virginia State Fair. Because participants selfselected participation in the State Fair Equine Skillathon, generalizations beyond the accessible population are not possible. 


\section{CHAPTER 2}

\section{Literature Review}

\section{Purpose of the Study}

This study was designed to determine West Virginia 4-H Horse program participants' equine knowledge. The focus of this study was the fundamental equine knowledge specifically related to horse breed identification, conformation, body and hoof parts, as well as feed identification that West Virginia junior and senior 4-H members who participated in the Equine Skillathon at the 2012 West Virginia State Fair possessed.

\section{4-H Projects}

Projects are a major curriculum emphasis in 4-H. From 1912 to today, projects have diversified from the basic corn, pigs, tomatoes, flowers, sewing, and canning topics to more than 100 project areas (Woloshuk, Brown, \& Wagaman, 1999). In the West Virginia 4-H program, a project is defined as a method for teaching girls and boys many new skills. A variety of topics are offered. Members share in setting goals, making decisions, learning, and evaluation (Woloshuk, et al., 1999). Project completion is defined by a three-fold process entailing a project exhibit as specified by a particular project, a completed project booklet, and a 4-H activity record. Project completion is frequently used to determine awards and recognition relative to the individual member's progress in 4-H (Woloshuk, et al., 1999). Each year, many questions arise regarding project selection, content, usage, costs, completion, and how this educational methodology for learning is beneficial to the youth participants. Demonstrating positive results, however, has been difficult and reported advantages to participation are often more suggestive than definitive (Woloshuk, et al., 1999). 
Though 4-H has expanded its educational initiatives beyond agriculture and farm based educational projects, agricultural science projects, and programming still remain a mainstream 4-H activity and provide a focus for county fairs and 4-H competitions. Extension personnel, parents, and youth often credit agricultural science projects and programming with teaching life and project skills. Stakeholders, legislators, and administrators want verifiable evidence of impacts, success stories, and testimonials that are no longer sufficient. There is a programmatic need for evidence that agricultural science projects and activities develop project and life skills in the youth participants (McKee, Talbert, \& Barkman, 2002; Mincemoyer \& Corbin, 2001; Schlink, 2000). Youth development professionals have evidence that 4-H animal science programs benefit participants by helping them develop valuable life skills. Several studies confirm that while young people are learning the skills of livestock production, they are also learning life skills that go beyond their projects. In an Oregon survey of 5,000 4-H members enrolled in animal science projects, a majority of the young people identified life-skills as the most important skills they learned from their projects (Sawer, 1987). In three southwestern states, 4-H members identified fairs and livestock shows as activities that developed the life skill of leadership (Seevers \& Dormody, 1994). Morris (1996) reported that Iowa 4-H members recorded a moderately high gain in leadership skills as a result of the 4-H experiences. Gamon and Dehegedus-Hetzel (1994) found that 4-H members with swine projects learned life skills. According to their findings, the main objective of 4-H programs, development of life skills, is being met in swine projects. The acquisition of subject-matter skills, however, could be balanced more with life skill development, as well as content skills. In a study conducted by Shurson and 
Lattner (1991), Ohio swine project members were studied to determine their fundamental swine production knowledge, and related career knowledge and life skills development. Overall, swine production knowledge gained was high, with $68 \%$ indicating they learned "some" or "much" about swine production and management. However, knowledge gained was more focused in the areas of fitting, showing, and selecting the ideal animal than for knowledge gained in the areas related to record keeping, management practices, health, reproduction, and nutrition.

Rusk, Martin, Talbert, and Balschweid (2003) compared county fair only exhibitors and Indiana State Fair exhibitors to determine if they had used information learned about their 4-H animal project(s) in their school science classes. A third of the respondents indicated they had used information about animal physiology in their science classes at school. 4-H animal experiences were reported to have helped in biology with life processes because they had hands on experience, animal nutrition helped with understanding energy conversion and requirements, 4-H livestock projects provided an understanding of body parts and the digestive system of a large animal, studying pedigrees allowed for an understanding of genetics, and breeding animals on the farm provided a basis for better understanding of genetics when it was taught in the classroom.

In a study conducted in Iowa by ISU Extension (1989) involving 4-H beef members and experts, identified 31 subject-matter topics and 30 life-skill topics that beef manuals should concentrate on. Emerging topics which should be added when developing manuals and conducting programs were those related to the concerns of consumers and the environment. It was also recommended that the value of some traditional topics, "showmanship," “care and grooming," and "competition" emphasized 
in 4-H livestock member manuals, should be examined; as well as the need to study the relationship between subject matter and life-skill topics.

A study of 4-H alumni by Radhakrishna and Sinasky (2005) recommended emphasis should be placed on new 4-H projects or revising 4-H curricula to reflect current technological trends. It suggested that classes such as biology, anatomy, biotechnology, computer technology in agriculture, and food science could have a positive effect on 4-H enrollment. An additional finding was that age-specific programs/projects need to be developed so that project books are appealing and challenging to youth.

\section{4-H Participation and Life Skills Development}

Numerous research studies have shown that 4-H involvement does promote and/or enhance life skill development in youth. A 1991 study conducted by Boyd, Herring, and Briers (1992) indicated participation in the 4-H program is positively related to perceived leadership life skill development. The study also indicated that the level of leadership life skill development increased as the level of 4-H participation increased (Boyd, et al., 1992). A study conducted by Fitzpatrick, Gagne, Jones, Lobley, and Phelps (2005) found that involvement in 4-H Youth Development Club programs does indeed help youth learn and use specific life skills. Their findings indicate that both youth and adults involved in 4-H display a high degree of satisfaction with the program. The study further suggests additional opportunities to assess the impacts of 4-H programs on youth development (Fitzpatrick, et al., 2005).

Anderson and Karr-Lilienthal (2011) studied 4-H Horse Project members who competed in non-riding horse contests to determine the influence involvement in the 
4-H Horse Project had on the development of life skills. They found a positive influence on both life-skill development and horse knowledge. A majority of the participants indicated that their life skills were enhanced (Anderson \& Karr-Lilienthal, 2011).

Other life skill development studies have been conducted regarding 4-H projects and their role in life skill development. Shurson and Lattner (1991) sought to determine if traditional 4- $\mathrm{H}$ project activities provide opportunities for participants to explore career options, be introduced to science and technology related to career choices, and develop fundamental life skills to become productive members of society. The study found that swine project members reported they learned the most about sportsmanship and working with others, followed by accepting responsibility, communicating with others, and making decisions. Leading a group and public speaking skills were areas where they learned the least from their swine project (Shurson \& Lattner, 1991).

Gamon and Dehegedus-Hetzel (1994) conducted two studies, one in 1990 and another in 1991, to determine how effective 4-H swine projects were in helping youth develop life skills and subject-matter skills. The two studies also addressed which sources of information were used to help support learning. In both studies, participants reported that participation in swine projects had a positive effect on their development of life skills and subject-matter skills. Findings indicate that parents were an important source of information (Gamon \& Dehegedus-Hetzel, 1994).

Ward (1996) studied life skill development related to participation in 4-H animal science projects. An alumni survey was conducted to determine the affect participation in 4-H animal science programs had on the development of life skills, such as spirit of inquiry, decision making, ability to relate to others, maintain records, public speaking, 
positive self-esteem, and ability to accept responsibility. Alumni were also asked how effective various events and activities were in developing life skills and if their involvement in 4-H animal science projects had any influence on their career choice. A positive relationship was found in all areas of the study (Ward, 1996).

Boleman, Cummings, and Briers (2004) studied parents' perceptions of life skills gained by youth participating in the 4-H beef project. Parents of 4-H youth were asked to indicate the influence their child participating in the 4-H beef project had on 13 life skills. They found the top five areas of influence were: accepting responsibility, setting goals, develop self-discipline, self-motivation, and knowledge of the livestock industry (Boleman, et al., 2004). They found a low-to-moderate positive relationship between life skill development and years of participating in the 4-H beef project (Boleman, et al., 2004).

Cole (2005) conducted a study about life skills learned through the 4-H Horse Program, H.A.Y. The goal of H.A.Y. (Horses and Youth program) was to provide prevention strategies for juvenile offenders and at-risk youth, ages 12 to 18 , by helping them gain competencies, self-confidence, group interaction capabilities, leadership skills, and opportunities to explore non-traditional vocations. The study found that the group that participated in the entire 26 week H.A.Y. project did show increases in all life skill areas as indicated through evaluation of pre- and post-life skill record data (Cole, 2005).

A study conducted by Smith, Swinker, Comerford, Radhakrishna, and Hoover (2006) looked at horsemanship and life skill development of youth in horse programs. The responding youth indicated that they were able to perform horsemanship skills related to handling, safety, and riding. Youth scored lower in nutrition and health 
management. The study found the youth reported they were able to perform life skills related to decision making, communicating, goal setting, thinking, and problem solving (Smith, et al., 2006).

\section{Experiential Learning in 4-H}

Experiential learning is not a new idea to the realm of education. Numerous individuals in academia have proposed learning models that resembled experiential learning. John Dewey, who is perhaps the most influential scholar in education of the twentieth century (Smith, 1997; Rusk, Summerlot-Early, Machtmes, Talbert, \& Balschweid, 2003), strongly believed in offering experiential learning opportunities to learners (Richardson, 1994).

Dewey (1938) stated:

...all principles by themselves are abstract. They become concrete only in the consequences which result from their application. Just because the principles set forth are so fundamental and far-reaching, everything depends upon the interpretation given them as they are put into practice in the school and the home. (p. 6)

Extension 4-H faculty and county-based academic staff have been developing and promoting experiential learning in 4-H for several decades (McCarther, Shields, \& Zurcher, 1987; Horton \& Konen, 1997; Horton, Hutchison, Barkman, Machtmes, \& Myers, 1999). Although a variety of models have been utilized in designing curricula and in developing training for 4- $\mathrm{H}$ volunteers and staff (Enfield, 2001), an experiential learning model using a five-step learning cycle based on the work of Kolb (1984) and Pfeiffer and Jones (1985) is the most common one currently used in 4-H Youth 
Development Programs as evidenced by the National 4-H Cooperative Curriculum System's materials.

\section{Science in 4-H}

To address increased demand for science and technology professionals, 4- $\mathrm{H}$ is working diligently to reach young people with science programs. 4-H Science programs are hands-on learning experiences, and the approach is comprehensive and holistic including agriculture, and animal sciences, while youth are learning about highly relevant complex systems and issues in their communities today. Barker (2007) gathered input from 4-H families concerning areas in which development of new science and technology programs should focus. The results indicated were six main theme areas: technology, agriculture, science, implementation ideas, self-efficacy, and miscellaneous. The study also found that parents felt new programs should be connected to traditional program areas, especially agriculture. Science education can be improved by immersing learners in the process of using scientific knowledge to "do" science oriented projects (Barker, 2007).

\section{Skillathons as an Educational Method}

According to Blalock and Strieter (2007), skillathons are used as experiential learning tools. A skillathon is a good method for intertwining the concepts of 4-H project knowledge, life-skill development, experiential learning, and science. A well-designed skillathon provides participants with opportunities to increase subject matter knowledge and skills. Skillathons are easy to implement, and participants have fun while learning. All skillathons are organized around four or five work stations, each emphasizing a different area of knowledge. Participants perform tasks that relate to a specific area, 
providing a challenging, experiential activity that promotes development of life skills and reinforces the project learning. Each activity is geared by age group to the level of development appropriate for the participant (junior, intermediate, or senior). Each station tests the participant's knowledge and ability in a particular subject (Blalock \& Strieter, 2007; VanWinkle, Davis, Skubinna, \& Larwood, 2005; Spike, 1997). The purposes of skillathons were to provide a learning laboratory that enhanced knowledge of the species and supports learning that occurs in 4-H youth project work.

When designed as a learning activity, a skillathon is comprised of a set of individual learning stations that host a specific activity to complete or a problem to solve. Participants learn as they use discovery and reflection to accomplish the task. Skillathons are often designed for several participants to work together. This enhances team building and reinforces communication and cooperative decision-making while increasing knowledge (Blalock \& Strieter, 2007).

Skillathons can also be used as an assessment tool (Blalock \& Strieter, 2007). Properly executed, a skillathon provides excellent program evaluation data, gathered in an exciting setting that minimizes "test" anxiety. This tool can virtually eliminate literacy difficulties that often plague paper and pencil assessments (Blalock \& Strieter, 2007).

Like an educational skillathon, an assessment skillathon is a set of individual stations with a specific activity for participants to complete or a problem to solve. The station evaluator ensures participants understand the instructions, and scores individuals based upon predetermined guidelines (Blalock \& Strieter, 2007). A skillathon is an excellent way to involve 4-H participants, leaders, and families in a fun "learning by 
doing" activity. Experienced older youth or family members can assist in planning and conducting a skillathon. Skillathons provide participants a chance to practice a skill or discover for themselves how to accomplish a task. These activities use the "Learning by Doing" philosophy and teach both the 4-H project areas being studied and life skills gained in 4-H (VanWinkle, et al., 2005).

\section{4-H Horse Program Studies}

A 2003 study conducted by Nadeau, Alger, Hoagland, and Chameroy (2004) focused on using a general knowledge exam to determine strengths and weaknesses of 4-H youth in six New England states competing at the Eastern States Exposition 4-H Horse Show. The Eastern States Exposition 4-H Horse Show was one of the culminating events of the year for the 4-H Horse Project in New England (Nadeau, et al., 2004). Residents of the six New England states of Connecticut, Massachusetts, Maine, New Hampshire, Rhode Island, and Vermont participated in horse fitting, showmanship and riding classes, competed in quiz bowl, and participants took a general knowledge exam (Nadeau, et al., 2004).

By categorizing questions on an exam, Nadeau et al. (2004) sought to determine strengths and weaknesses of 4-H youth in ten different categories of horse knowledge. The ten categories included: anatomy and physiology, breeding, colors, conformation, health and disease, history and evolution, nutrition, reproduction, tack and equipment, and training and behavior.

Nadeau et al. (2004) found that age, discipline, and years of participation differed significantly. Participants who were 13, 14, and 15 years old had lower mean scores than 16, 17, 18, and 19 year old participants. There were no differences based on gender. 
With respect to discipline, junior leaders scored lower than participants who rode hunt seat, saddle seat, or western. Hunt seat riders scored higher than western riders, but there were no other significant differences. No differences were found between first-time participants and previous participants. Scores of previous participants increased, until reaching a maximum score upon the third year of attendance. After that, no improvement was shown based on years of attendance. Mean state and category scores were different as main effects (Nadeau, et al., 2004). Two states had higher mean scores than any of the other participating states. The highest mean scores were in the categories of health and disease, breeds, colors and markings, and anatomy and physiology, followed by tack and equipment and training, followed by nutrition. The lowest mean scores were in reproduction, conformation, and history and evolution (Nadeau, et al., 2004).

The organizers of the 2003 study by Nadeau et al. (2004) continued the project with the support of the New England 4-H Horse Show Committee in 2004 and 2005 to longitudinally track the 4-H members of the participating states (Nadeau, Alger, \& Hoagland, 2007). Focusing on one aspect of program participation, such as the general knowledge exam, afforded a chance to study changes in a particular program area. The longitudinal study helped to track progress over time of 4-H youth and assess the effectiveness of targeted programming in the participating states (Nadeau, et al., 2007).

Age, discipline, repetition (how many years the participant had taken the exam), state the youth was registered in, and year of the test differed significantly (Nadeau, et al., 2007). Mean scores were highest for 18,17, 19 and 16 year old participants followed by 15,13 , and 14 year old participants, respectively. Once again, there were no significant differences based on gender (Nadeau, et al., 2007). When the results of the longitudinal 
study were sorted by discipline, hunt seat riders had the highest mean score, followed by western riders, saddle seat riders, and junior leaders. Hunt seat riders scored higher than western riders and junior leaders (Nadeau, et al., 2007).

4-H members that participated in the event for six years, the longest available, had the highest mean score, followed by participants of three years, five years, four years, two years, followed by first-year participants (Nadeau, et al., 2007). Participants of three years had a higher mean score than four-year and five-year participants, as well as a higher mean score than first- and second-year participants (Nadeau, et al., 2007). The highest mean scores were in the categories of health and disease, breeds, colors and markings, and anatomy and followed by tack and equipment and training, then by conformation physiology. The lowest mean scores were in reproduction, nutrition, and history and evolution (Nadeau, et al., 2007).

A study conducted by Beck, Rayfield, Flowers, and Jones (2010) assessed ground safety knowledge of 4-H Horse Program participants in the North Carolina 4-H Horse Camp. By understanding current levels of horse ground safety, programming could be developed to increase safety in the equestrian sport (Beck, et. al, 2010). Camp participants were assessed on safety skills in four separate areas: leading safety, stall safety, grooming safety, and total safety score. Camp participants posted the highest scores on stall safety and the lowest scores on leading safety (Beck, et. al, 2010). Based on their low ground safety mean scores, the 4-H members in the study did not follow good basic ground safety practices with horses; previous research discusses the high risk of horse-related activities, as well as the cost and fatality rates associated with these accidents. However, research suggests that some accidents could be avoided if proper 
precautions were taken. The low mean ground safety scores found in the study, particularly in the area of leading, support these assertions (Beck, et. al, 2010). 


\section{CHAPTER 3}

\section{Methodology}

\section{Purpose of the Study}

This study was designed to determine West Virginia 4-H Horse program participants' equine knowledge. The focus of this study was the fundamental equine knowledge specifically related to horse breed identification, conformation, body and hoof parts, as well as feed identification that West Virginia junior and senior 4-H members who participated in the Equine Skillathon at the 2012 West Virginia State Fair possessed.

\section{Research Questions and Hypotheses}

The objectives of the study are reflected in the following research questions:

1. What are the 2012 State Fair Equine Skillathon participants' knowledge of breeds of horses?

2. What are the 2012 State Fair Equine Skillathon participants' knowledge of the body parts of a horse?

3. What are the 2012 State Fair Equine Skillathon participants' knowledge of conformational faults and abnormalities?

4. What are the 2012 State Fair Equine Skillathon participants' knowledge of the parts of a horse's hoof?

5. What are the 2012 State Fair Equine Skillathon participants' knowledge of feed types and ingredients?

6. Is there an association between members' years of 4-H participation and their fundamental equine knowledge? 
7. Is there an association between members' years of participation in the 4-H Horse Project and their fundamental equine knowledge?

8. Is there an association between a 4-H member having shown at a County 4- $\mathrm{H}$ Horse Show and their fundamental equine knowledge?

9. Is there an association between a 4-H member having participated in the Equine Skillathon at the West Virginia State Fair and their fundamental equine knowledge?

The following hypotheses were used:

Null 1: There was no association between the 2012 State Fair Equine Skillathon participants' years of participation in 4-H and their fundamental equine knowledge. Research 1: There was an association between the 2012 State Fair Equine Skillathon participants' years of participation in 4-H and their fundamental equine knowledge. Null 2: There was no association between the 2012 State Fair Equine Skillathon participants' years of participation in the 4-H Horse project and their fundamental equine knowledge.

Research 2: There was an association between the 2012 State Fair Equine Skillathon participants' years of participation in the 4-H Horse project and their fundamental equine knowledge.

Null 3: There was no association between the 2012 State Fair Equine Skillathon participants' years of participation in a County 4-H Horse Show and their fundamental equine knowledge. 
Research 3: There was an association between the 2012 State Fair Equine Skillathon participants' years of participation in a County 4-H Horse Show and their fundamental equine knowledge.

Null 4: There was no association between the 2012 State Fair Equine Skillathon participants' years of participation in the State Fair Junior Horse and Pony Show and their fundamental equine knowledge.

Research 4: There was an association between the 2012 State Fair Equine Skillathon participants' years of participation in the State Fair Junior Horse and Pony Show and their fundamental equine knowledge.

Null 5: There was no association between the 2012 State Fair Equine Skillathon participants' years of participation in the State Fair Equine Skillathon and their fundamental equine knowledge.

Research 5: There was an association between the 2012 State Equine Skillathon participants' years of participation in the State Fair Equine Skillathon and their fundamental equine knowledge.

\section{Research Design}

A descriptive research design was used to look at the fundamental equine knowledge of junior and senior 4-H members who participated in the Equine Skillathon at the 2012 West Virginia State Fair. A descriptive research design was appropriate for this study, due to the nature of the instrumentation and the data collection. The score sheets from the Equine Skillathon at the 2012 West Virginia State Fair were used to collect data. The researcher, in collaboration with Agricultural and Extension Education faculty and Extension personnel at West Virginia University, designed the Equine 
Skillathon event to measure certain information areas and so that the Junior and Senior sections paralleled each other for comparative purposes. The score sheets were obtained by the researcher after the conclusion of the event, from which all participant names had been removed from the score sheets.

\section{Population}

In Department F: State 4-H and FFA Junior Livestock Show at the West Virginia State Fair, participants in the Junior Division must be nine years old or in the third grade during the current 4-H year, which is from October 1 to September 30, and may not have reached their 14 year old birthday on or before January 1. In the Senior Division, participants must be at least 14 years old on or before January 1, and may not have reached their 21 year old birthday on or before January 1 (The State Fair of West Virginia Exhibitors’ Guide, 2012).

The target population was all junior and senior 4-H members who participated in the 4-H Horse program in West Virginia. The accessible sample consisted of all 4-H members who took part in the Equine Skillathon at the 2012 West Virginia State Fair. Because participants self-selected participation in the State Fair Equine Skillathon, generalizations beyond the accessible population was limited. Twenty-eight 4-H members participated in the 2012 State Fair Equine Skillathon; no FFA members participated in the 2012 State Fair Equine Skillathon.

\section{Instrumentation}

The instrument used was the content for the Equine Skillathon held during the 2012 West Virginia State Fair. Junior and senior 4-H members were given the same five skillathon events: breed identification, conformation, body and hoof parts, and feed 
identification (see Appendix A). The photos, diagrams, and feed samples included in the Horse Learning Laboratory Kit (Ohio 4-H Youth Development, 2012) were used in the five skillathon events. The senior 4-H members were also required to answer five multiple choice questions (see Appendix B).

In the breed identification category, the 4-H members were asked to identify seven breeds of horses. They were provided pictures of each breed and labels with the names of the breeds to match with the appropriate picture. The breeds used for the skillathon were the American Saddlebred, Arabian, Paint, Palomino, Quarter Horse, Tennessee Walking Horse, and Thoroughbred (see Appendix A).

In the conformation category, 4-H members were asked to identify conformational faults and abnormalities from the front view of the horse. They were provided pictures of four conformational faults/abnormalities and one of an ideal horse, and labels with the name of each possible answer to match with the appropriate picture were provided. The conformational faults/abnormalities given were base narrow, bow legged, knock kneed, and pigeon toed (see Appendix A).

The 4-H members were asked to label five parts of a horse's hoof on a diagram using the sole view of a hoof. They were provided labels of the five parts that they were to match with the appropriate areas marked with a line on the hoof diagram. The five parts of a hoof included the frog, heel bulbs, hoof wall, the sole, and the white line (see Appendix A).

4-H members were asked to label five parts of a horse's body. They were provided labels of the five parts that they needed to label to match with the lines on a 
diagram of a horse's body. The five parts included the back, the pastern, the point of shoulder, the stifle, and the throat latch (see Appendix A).

Feed types and ingredients was the last category both junior and senior members identified. 4-H members were provided five feed samples in small jars to identify. Labels were provided to match with the appropriate feed sample. The feeds provided for identification were dehydrated alfalfa meal pellets, dicalcium phosphate, trace mineral salt in salt, whole grain oats, and whole grain wheat (see Appendix A).

In addition to the five categories described above, the senior 4-H members were given five multiple choice questions to answer (see Appendix B). Both junior and senior 4-H members were asked to provide demographic information as they completed their score sheet (see Appendix C).

\section{Validity of the Instrument}

The instrument, which utilized photos, diagrams, and feed samples from the Horse Learning Laboratory Kit (Ohio 4-H Youth Development, 2012), was presented to a panel of faculty members in Agricultural and Extension Education at West Virginia University and the 2012 State Fair Equine Skillathon coordinator to establish content and face validity. Each individual on the panel had extensive teaching and/or Extension experience. The panel determined that the instrument had content and face validity.

\section{Reliability of the Instrument}

The reliability of the instrument was determined using the final data set. The data consisted of nominal and ordinal scale responses; therefore, a Spearman-Brown split half statistic was used to establish the instrument's reliability. The reliability was found to be 
extensive with a coefficient of 0.752 (Robinson, Shaver, \& Wrightsman, 1991). The instrument was established as a reliable measure.

\section{Data Collection Procedures}

Data were collected using the score sheet that was used for the Equine Skillathon held during the 2012 West Virginia State Fair. Junior and senior 4-H members were given the same five skillathon events: breed identification, conformation, body and hoof parts, and feed identification set up at different tables for each division (see Appendix A). The senior 4-H members were also required to answer five multiple choice questions (see Appendix B).

The skillathon was set up using two rows of four tables, so that the junior members could go through the skillathon down one row of tables and the senior members could go down the other row of tables on opposite sides of the contest area. Tables in each row had identical activities for both member levels, but were set up so that the same event was not directly across from the same event in the other division. Materials were taken from two Horse Learning Laboratory Kits, which contain standardized photos, diagrams, and feed samples used to teach equine knowledge, with accompanying labels needed to identify the material in question (Ohio 4-H Youth Development, 2012). The feed samples in small glass containers were set up on one table to the back of the contest area for both junior and senior members, who took turns approaching the event table.

Event judges with the correct answers sat at each table and invited each individual contestant to approach the table one person at a time. The contestant was to read the score sheet with instructions and appropriately label the items in question given the labels provided. Once the contestant indicated that they were satisfied with their answers, the 
judge at that table scored their answers, wrote the number of items correct on the contestant's score sheet, and quietly indicated to the contestant the correct answers. In the breed identification category, the maximum possible points was seven, while for the areas of conformation, body and hoof parts, and feed identification, the maximum possible points was five. The contestant then moved on to the queue for the next table. Adult supervisors not related to the participants were present to assist with keeping participants waiting a distance back from the contest tables, so that they could not see the questions or overhear the correct answers provided to the previous contestant.

Senior participants, one at a time, sat at the official score table to complete their responses to the five multiple choice questions, which had maximum possible points of five. Both junior and senior participants completed demographic information requested on the score sheet at the scorer's table, and then the score sheets were submitted at the scorer's table. The official scorers scored the senior multiple choice questions and tallied and recorded the participants' overall scores for correct responses for both divisions. Junior participants had a maximum of 27 possible points, while the senior participants had a maximum of 32 possible points. The participants' scores were determined by adding up the number of correct answers. Score sheets were collected by the scorers, and a contest record was created of all scores and the top scorers in each category were determined and results given to the contest coordinator. All contestant score sheets were given to the contest coordinator, who removed all names from the score sheets before providing them to the researcher.

Score sheets were divided by junior and senior divisions, and each score sheet was given a number for recording purposes. Scores from each section of the score sheet 
were entered into an Excel database, along with demographic information and division identifiers for each contestant. The data was then analyzed using SPSS software.

\section{Use of Findings}

The findings of this study will used by Extension professionals, 4-H leaders, and other individuals when working with 4-H youth to improve their fundamental equine knowledge. The findings of this research can be used in developing educational activities for horse project participants and leaders to increase equine knowledge. 


\section{CHAPTER 4}

\section{Findings}

\section{Purpose of the Study}

This study was designed to determine West Virginia 4-H Horse program participants' equine knowledge. The focus of this study was the fundamental equine knowledge specifically related to horse breed identification, conformation, body and hoof parts, as well as feed identification that West Virginia junior and senior 4-H members who participated in the Equine Skillathon at the 2012 West Virginia State Fair possessed.

\section{Research Questions and Hypotheses}

The objectives of the study are reflected in the following research questions:

1. What are the 2012 State Fair Equine Skillathon participants' knowledge of breeds of horses?

2. What are the 2012 State Fair Equine Skillathon participants' knowledge of the body parts of a horse?

3. What are the 2012 State Fair Equine Skillathon participants' knowledge of conformational faults and abnormalities?

4. What are the 2012 State Fair Equine Skillathon participants' knowledge of the parts of a horse's hoof?

5. What are the 2012 State Fair Equine Skillathon participants' knowledge of feed types and ingredients?

6. Is there an association between members' years of 4-H participation and their fundamental equine knowledge? 
7. Is there an association between members' years of participation in the 4-H Horse Project and their fundamental equine knowledge?

8. Is there an association between a 4-H member having shown at a County 4- $\mathrm{H}$ Horse Show and their fundamental equine knowledge?

9. Is there an association between a 4-H member having participated in the Equine Skillathon at the West Virginia State Fair and their fundamental equine knowledge?

The following hypotheses were used:

Null 1: There was no association between the 2012 State Fair Equine Skillathon participants' years of participation in 4-H and their fundamental equine knowledge. Research 1: There was an association between the 2012 State Fair Equine Skillathon participants' years of participation in 4-H and their fundamental equine knowledge. Null 2: There was no association between the 2012 State Fair Equine Skillathon participants' years of participation in the 4-H Horse project and their fundamental equine knowledge.

Research 2: There was an association between the 2012 State Fair Equine Skillathon participants' years of participation in the 4-H Horse project and their fundamental equine knowledge.

Null 3: There was no association between the 2012 State Fair Equine Skillathon participants' years of participation in a County 4-H Horse Show and their fundamental equine knowledge. 
Research 3: There was an association between the 2012 State Fair Equine Skillathon participants' years of participation in a County 4-H Horse Show and their fundamental equine knowledge.

Null 4: There was no association between the 2012 State Fair Equine Skillathon participants' years of participation in the State Fair Junior Horse and Pony Show and their fundamental equine knowledge.

Research 4: There was an association between the 2012 State Fair Equine Skillathon participants' years of participation in the State Fair Junior Horse and Pony Show and their fundamental equine knowledge.

Null 5: There was no association between the 2012 State Fair Equine Skillathon participants' years of participation in the State Fair Equine Skillathon and their fundamental equine knowledge.

Research 5: There was an association between the 2012 State Equine Skillathon participants' years of participation in the State Fair Equine Skillathon and their fundamental equine knowledge.

\section{4-H Members’ Participation}

Twenty-eight 4-H members participated in the Equine Skillathon during the 2012 West Virginia State Fair. Of the participants, 14 (50.0\%) were junior 4-H members and $14(50.0 \%)$ were senior 4-H members (see Table 1).

The 2012 State Fair Equine Skillathon participants were asked to identify their home county. The state of West Virginia has 55 counties, and the participants represented 10 of those counties. The counties that were represented were Berkeley, 
Braxton, Greenbrier, Hampshire, Hardy, Jefferson, Mineral, Pocahontas, Preston, and Raleigh Counties.

Table 1

4-H Status of 2012 State Fair Equine Skillathon Participants

\begin{tabular}{lcc}
\hline & $\mathrm{N}$ & $\%$ \\
\hline Junior & 14 & 50.0 \\
Senior & 14 & 50.0 \\
\hline
\end{tabular}

The 2012 State Fair Equine Skillathon participants were asked to identify if they had participated in a County 4-H Horse Show. Of the 28 participants, $21(75 \%)$ had participated in a County 4-H Horse Show (see Table 2). Seven (25\%) participants have not participated in a County 4-H Horse Show.

The 2012 State Fair Equine Skillathon participants were asked to identify if they had ever participated in the State Fair Junior Horse and Pony Show. Of the 28 participants, $21(75 \%)$ of them had also participated in the State Fair Junior Horse and Pony Show (see Table 2). Seven (25\%) participants had not participated in the State Fair Junior Horse and Pony Show.

The 2012 State Fair Equine Skillathon participants were asked to identify if they had ever participated in the State Fair Equine Skillathon. Of the 28 participants, 21 $(75 \%)$ of them had participated in the State Fair Equine Skillathon (see Table 2). Seven (25\%) participants had not participated in the State Fair Equine Skillathon. 
Table 2

4-H Members Participation in Events

\begin{tabular}{lcccc}
\hline & \multicolumn{2}{c}{ Yes } & \multicolumn{2}{c}{ No } \\
\cline { 2 - 5 } & $\mathrm{N}$ & $\%$ & $\mathrm{~N}$ & $\%$ \\
\hline County 4-H Horse Show & 21 & 75.0 & 7 & 25.0 \\
$\begin{array}{l}\text { State Fair Junior Horse and Pony } \\
\text { Show }\end{array}$ & 21 & 75.0 & 7 & 25.0 \\
State Fair Equine Skillathon & 21 & 75.0 & 7 & 25.0 \\
\hline
\end{tabular}

\section{4-H Members’ Scores}

The 2012 State Fair Equine Skillathon consisted of five categories for the junior 4-H members and six categories for the senior 4-H members. Categories for both groups included: breed identification, conformation, body and hoof parts, and feed identification (see Table 3). The senior 4-H members also answered five multiple choice questions. The maximum score for breed identification was 7.00 points, while the maximum scores for the other four categories and the multiple choice questions were 5.00 points each.

The 2012 State Fair Equine Skillathon participants were asked to identify seven equine breeds. The overall mean score for breed identification was 4.32 points; with a standard deviation of 1.79 (see Table 3). For the junior 4-H members, the mean score for the breed identification was 4.00 points, with a standard deviation of 1.41 ; while the mean score for senior members was 4.64 points, with a standard deviation of 2.10 .

The 2012 State Fair Equine Skillathon participants were asked to identify five conformational faults and abnormalities. The overall mean score for conformation was 3.36 points; with a standard deviation of 1.54 (see Table 3 ). The conformation mean 
score for juniors was 2.36 points, with a standard deviation of 1.39 ; while the mean score for seniors was 4.36 points, with a standard deviation of 0.93 .

The 2012 State Fair Equine Skillathon participants were asked to identify five parts of the horse's hoof. The overall mean score for hoof parts was 3.32 points; with a standard deviation of 1.16 (see Table 3). The mean score for juniors for hoof parts was 2.93 points, with a standard deviation of 1.44 and the seniors' mean score was 3.71 points, with a standard deviation of 0.61 .

The 2012 State Fair Equine Skillathon participants were asked to identify five parts of the horse's body. The overall mean score for body parts was 2.89 points, with a standard deviation of 1.03 (see Table 3). The mean score for juniors on body parts was 2.64 points, with a standard deviation of 0.93 ; the mean score for seniors was 3.14 points, with a standard deviation of 1.10 .

The 2012 State Fair Equine Skillathon participants were asked to identify five types of feed ingredients. The overall mean score for the feeds identification was 3.43 points, with a standard deviation of 1.48. The mean score for juniors in feeds identification was 3.14 points, with a standard deviation of 1.46; senior mean score was 3.71 points, with a standard deviation of 1.49 . The overall mean score for seniors on the multiple choice questions was 2.36 points; with a standard deviation of 1.08 (see Table 3). 
Table 3

Scores Earned in Each Category of the 2012 State Fair Equine Skillathon

\begin{tabular}{lccccccc}
\hline & Max. & \multicolumn{7}{c}{ Rank in 4-H } \\
\cline { 3 - 8 } & & \multicolumn{2}{c}{ Score } & \multicolumn{2}{c}{ Senior } & \multicolumn{2}{c}{ Total } \\
\cline { 3 - 8 } & & M & SD & M & SD & M & SD \\
\hline Breeds ID & 7.00 & 4.00 & 1.41 & 4.64 & 2.10 & 4.32 & 1.79 \\
Conformation & 5.00 & 2.36 & 1.39 & 4.36 & 0.93 & 3.36 & 1.54 \\
Hoof Parts & 5.00 & 2.93 & 1.44 & 3.71 & 0.61 & 3.32 & 1.16 \\
Body Parts & 5.00 & 2.64 & 0.93 & 3.14 & 1.10 & 2.89 & 1.03 \\
Feeds ID & 5.00 & 3.14 & 1.46 & 3.71 & 1.49 & 3.43 & 1.48 \\
Skillathon & & & & & & & \\
Questions & 5.00 & & & 2.36 & 1.08 & 2.36 & 1.08 \\
\hline
\end{tabular}

\section{4-H Members’ Event Participation}

Junior and senior 4-H members who participated in the 2012 State Fair Equine

Skillathon were asked to indicate how many years they had participated in 4-H, the 4-H Horse Project, a County 4-H Horse Show, the State Fair Junior Horse and Pony Show, and the State Fair Equine Skillathon (see Table 4).

The 2012 State Fair Equine Skillathon participants were asked to indicate how many years they had participated in 4-H. The mean for total number of years of participation was 5.75 years, with a standard deviation of 3.30 (see Table 4). For junior 4-H members, the mean was 4.14 years, with a standard deviation of 2.48. For senior 4-H members, the mean was 7.36 years, with a standard deviation of 3.30 . 
The 2012 State Fair Equine Skillathon participants were asked to indicate how many years they had participated in the 4-H Horse Project. The mean for total number of years of participation was 4.64 years, with a standard deviation of 3.28. The junior mean was 3.14 years, with a standard deviation of 2.03; the senior mean was 6.14 years, with a standard deviation of 3.66 .

The 2012 State Fair Equine Skillathon participants were asked to indicate how many years they had participated in a County 4-H Horse Show. The mean for total number of years of participation was 3.96 years, with a standard deviation of 3.27. The mean for juniors was 2.93 years, with a standard deviation of 2.34 , while the senior mean was 5.00 years, with a standard deviation of 3.80 .

The 2012 State Fair Equine Skillathon participants were asked to indicate how many years they had participated in the State Fair Junior Horse and Pony Show. The mean for total number of years of participation was 3.21 years, with a standard deviation of 2.81. The mean for junior participation was 2.29 years, with a standard deviation of 2.73 , with a senior mean of 4.14 years, with a standard deviation of 2.66 .

The 2012 State Fair Equine Skillathon participants were asked to indicate how many years they had participated in the State Fair Equine Skillathon. The mean for total number of years of participation was 2.50 years, with a standard deviation of 2.13. The mean for participation by juniors was 1.50 years, with a standard deviation of 1.29 , while the mean for seniors was 3.50 years, with a standard deviation of 2.38 . 
Table 4

Years of Participation in Various Events

\begin{tabular}{lcccccc}
\hline & \multicolumn{5}{c}{ Rank in 4-H } \\
\cline { 2 - 7 } & \multicolumn{2}{c}{ Junior } & \multicolumn{2}{c}{ Senior } & \multicolumn{2}{c}{ Total } \\
\cline { 2 - 7 } & M & SD & M & SD & M & SD \\
\hline 4-H & 4.14 & 2.48 & 7.36 & 3.30 & 5.75 & 3.30 \\
4-H Horse Project & 3.14 & 2.03 & 6.14 & 3.66 & 4.64 & 3.28 \\
County 4-H Horse Show & 2.93 & 2.34 & 5.00 & 3.80 & 3.96 & 3.27 \\
State Fair Junior Horse and Pony & 2.29 & 2.73 & 4.14 & 2.66 & 3.21 & 2.81 \\
Show & & & & & & \\
State Fair Equine Skillathon & 1.50 & 1.29 & 3.50 & 2.38 & 2.50 & 2.13 \\
\hline
\end{tabular}

\section{Senior Member Multiple Choice Questions}

The senior 4-H members were given five multiple choice questions to answer (see Appendix B) in addition to the five categories of breed identification, conformation, body and hoof parts, and feed identification (see Table 5). Their score was determined as to whether or not the members answered each question correctly. One point was given for each correct answer for a maximum of five points possible.

Of the 14 senior members who participated in the 2012 State Fair Equine Skillathon, three (21.4\%) participants answered Question 1, "Hot horses or horses that have been deprived of water should not be given large quantities of water at one time, because what 2 conditions may occur?" correctly (see Table 5). Eight (57.1\%) of the participants answered Question 2, "What is the term for the total protein content present in a given feed?" correctly, while two (14.3\%) participants answered Question 3, "Hay 
can be a fire hazard when it is moisture" correctly. Ten $(71.4 \%)$ of the senior participants answered Question 4, "What is the average temperature of a horse?" and Question 5, “A horse has how many knees?” correctly (see Appendix B).

Table 5

Senior 4-H Members’ Knowledge Questions

\begin{tabular}{lcc}
\hline & $\mathrm{N}$ & Correct Answer \\
\cline { 2 - 3 } & & \\
\hline $\begin{array}{l}\text { Question 1: Hot horses or horses that have been } \\
\text { deprived of water should not be given large } \\
\text { quantities of water at one time, because what } \\
\text { conditions may occur? }\end{array}$ & 3 & 21.4 \\
$\begin{array}{l}\text { Question 2: What is the term for the total } \\
\text { protein content present in a given feed }\end{array}$ & 8 & 57.1 \\
$\begin{array}{l}\text { Question 3: Hay can be a fire hazard when it is } \\
\text { moisture. }\end{array}$ & 2 & 14.3 \\
\hline $\begin{array}{l}\text { Question 4: What is the average temperature of } \\
\text { a horse? }\end{array}$ & 10 & 71.4 \\
\begin{tabular}{l} 
Question 5: A horse has how many knees? \\
\hline
\end{tabular} & 10 & 71.4 \\
\hline
\end{tabular}

\section{4-H Members' Composite Scores}

The junior 4-H members had a maximum score of 27 points available for the 2012 State Fair Equine Skillathon, while the senior 4-H members had a maximum score of 32 points available, due to the five additional points possible from the multiple choice questions (see Table 6). The total mean composite score for both groups was 18.50 points, with a standard deviation of 5.40. The junior 4-H members' mean composite score was 15.07 points, with a standard deviation of 3.50. The senior 4-H members' mean composite score was 21.93 points, with a standard deviation of 4.80 . 
Table 6

Composite Results of the 2012 State Fair Equine Skillathon

\begin{tabular}{lcccccc}
\hline & \multicolumn{9}{c}{ Rank in 4-H } \\
\cline { 2 - 7 } & \multicolumn{2}{c}{ Junior $(\max =27)$} & \multicolumn{2}{c}{ Senior $(\max =32)$} & \multicolumn{2}{c}{ Total } \\
\cline { 2 - 7 } Composite Score & 15.07 & 3.50 & 21.93 & 4.80 & 18.50 & 5.40 \\
\hline
\end{tabular}

Associations between Years of Participation and Fundamental Equine Knowledge

Twenty-eight 4-H members participated in the Equine Skillathon at the 2012 West Virginia State Fair (Table 7). The overall mean for years of participation in 4-H was 5.75 years, with a standard deviation of 3.296 . The skewness was 0.485 , and the kurtosis was -0.330 .

Twenty-eight 4-H members participated in the Equine Skillathon at the 2012 West Virginia State Fair (Table 7). The overall mean for years of participation in the 4-H Horse Project was 4.64 years, with a standard deviation of 3.280. The skewness was 0.966 , and the kurtosis was 0.674 .

Twenty-eight 4-H members participated in the Equine Skillathon at the 2012 West Virginia State Fair (Table 7). The overall mean for years of participation in a County 4-H Horse Show was 3.96 years, with a standard deviation of 3.271. The skewness was 0.670 , and the kurtosis was 0.707 .

Twenty-eight 4-H members participated in the Equine Skillathon at the 2012 West Virginia State Fair (Table 7). The overall mean for years of participation in the 
State Fair Junior Horse and Pony Show was 3.21 years, with a standard deviation of 2.807. The skewness was 0.640 , and the kurtosis was -0.354 .

Twenty-eight 4-H members participated in the Equine Skillathon at the 2012 West Virginia State Fair (Table 7). The overall mean for years of participation in the State Equine Skillathon was 2.50 years, with a standard deviation of 2.134. The skewness was 0.714 , and the kurtosis was 0.175 .

Table 7

Descriptive Statistics for Years of Participation in Events

\begin{tabular}{lccccc}
\hline \multicolumn{1}{c}{ Event } & $\mathrm{N}$ & $\mathrm{M}$ & $\mathrm{SD}$ & Skewness & Kurtosis \\
\hline 4-H & 28.0 & 5.75 & 3.296 & 0.485 & -0.330 \\
4-H Horse Project & 28.0 & 4.64 & 3.280 & 0.966 & 0.674 \\
$\begin{array}{l}\text { County 4-H Horse Show } \\
\begin{array}{l}\text { State Fair Junior Horse } \\
\text { and Pony Show }\end{array}\end{array}$ & 28.0 & 3.96 & 3.271 & 0.670 & 0.707 \\
$\begin{array}{l}\text { State Fair Equine } \\
\text { Skillathon }\end{array}$ & 28.0 & 3.21 & 2.807 & 0.640 & -0.354 \\
\hline
\end{tabular}

A Pearson's product moment correlation coefficient was calculated to determine the relationship between the 2012 State Fair Equine Skillathon participants' years of participation in 4-H and their fundamental equine knowledge (see Table 8). The null hypothesis was there was no association between the 2012 State Fair Equine Skillathon participants' years of participation in 4-H and their fundamental equine knowledge. The research hypothesis was there was an association between the 2012 State Fair Equine Skillathon participants' years of participation in 4-H and their fundamental equine knowledge. The Pearson's $r$ statistical procedure was not significant $(r=.068, \alpha \leq .05)$. 
The researcher failed to reject the null hypothesis. There was no relationship between the 2012 State Fair Equine Skillathon participants' years of participation in 4-H and their fundamental equine knowledge.

Table 8

Association between Years of Participation in 4-H and Fundamental Equine Knowledge

\begin{tabular}{lc}
\hline & Value \\
\hline Pearson's $r$ & .068 \\
\hline
\end{tabular}

$* \alpha \leq .05$

A Pearson's product moment correlation coefficient was calculated to determine the relationship between the 2012 State Fair Equine Skillathon participants' years of participation in the 4-H Horse project and their fundamental equine knowledge (see Table 9). The null hypothesis was there was no association between the 2012 State Fair Equine Skillathon participants' years of participation in the 4-H Horse project and their fundamental equine knowledge. The research hypothesis was there was an association between the 2012 State Fair Equine Skillathon participants' years of participation in the 4-H Horse project and their fundamental equine knowledge. The Pearson's $r$ statistical procedure was significant $(r=.015, \alpha \leq .05)$. The null hypothesis was rejected, and the research hypothesis was accepted. Using Cohen's convention (1988) for describing the magnitude of a relationship, researchers found a small effect size between the 2012 State Fair Equine Skillathon participants' years of participation in the 4-H Horse project and their fundamental equine knowledge. Therefore, it can be concluded that as a participants' years of participation in the 4-H Horse project increases, his or her fundamental equine knowledge increases. 
Table 9

Association Between Years of Participation in the 4-H Horse Project and Fundamental Equine Knowledge

\begin{tabular}{ll}
\hline & Value \\
\hline Pearson's $r$ & $.015^{*}$ \\
\hline$* \alpha \leq .05$ &
\end{tabular}

A Pearson's product moment correlation coefficient was calculated to determine the relationship between the 2012 State Fair Equine Skillathon participants' years of participation in a County 4-H Horse Show and their fundamental equine knowledge (see Table 10). The null hypothesis was there was no association between the 2012 State Fair Equine Skillathon participants' years of participation in a County 4-H Horse Show and their fundamental equine knowledge. The research hypothesis was there was an association between the 2012 State Fair Equine Skillathon participants' years of participation in a County 4-H Horse Show and their fundamental equine knowledge. The Pearson's $r$ statistical procedure was significant $(r=.030, \alpha \leq .05)$. The null hypothesis was rejected, and the research hypothesis was accepted. Using Cohen's convention (1988) for describing the magnitude of a relationship, researchers found a medium effect size between the 2012 State Fair Equine Skillathon participants' years of participation a County 4-H Horse Show and their fundamental equine knowledge. Therefore, it can be concluded that as a participants' years of participation in a County 4-H Horse Show increases, his or her fundamental equine knowledge increases. 
Table 10

Association Between Years of Participation in a County 4-H Horse Show and Fundamental Equine Knowledge

\begin{tabular}{ll}
\hline & Value \\
\hline Pearson's $r$ & $.030^{*}$ \\
\hline$* \alpha \leq .05$ &
\end{tabular}

A Pearson's product moment correlation coefficient was calculated to determine the relationship between the 2012 State Fair Equine Skillathon participants' years of participation in the State Fair Junior Horse and Pony Show and their fundamental equine knowledge (see Table 11). The null hypothesis was there was no association between the 2012 State Fair Equine Skillathon participants' years of participation in the State Fair Junior Horse and Pony Show and their fundamental equine knowledge. The research hypothesis was there was an association between the 2012 State Fair Equine Skillathon participants' years of participation in the State Fair Junior Horse and Pony Show and their fundamental equine knowledge. The Pearson's $r$ statistical procedure was significant $(r=.012, \alpha \leq .05)$. The null hypothesis was rejected, and the research hypothesis was accepted. Using Cohen's convention (1988) for describing the magnitude of a relationship, researchers found a small effect size between the 2012 State Fair Equine Skillathon participants' years of participation the State Fair Junior Horse and Pony Show and their fundamental equine knowledge. Therefore, it can be concluded that as a participants' years of participation in the State Fair Junior Horse and Pony Show increases, his or her fundamental equine knowledge increases. 
Table 11

Association Between Years of Participation in the State Fair Junior Horse and Pony Show and Fundamental Equine Knowledge

\begin{tabular}{ll}
\hline & Value \\
\hline Pearson's $r$ & $.012^{*}$ \\
\hline$* \alpha \leq .05$ &
\end{tabular}

A Pearson's product moment correlation coefficient was calculated to determine the relationship between the 2012 State Fair Equine Skillathon participants' years of participation in the State Fair Equine Skillathon and their fundamental equine knowledge (see Table 12). The null hypothesis was there was no association between the 2012 State Fair Equine Skillathon participants' years of participation the State Fair Equine Skillathon and their fundamental equine knowledge. The research hypothesis was there was an association between the 2012 State Fair Equine Skillathon participants' years of participation in the State Fair Equine Skillathon and their fundamental equine knowledge. The Pearson's $r$ statistical procedure was significant $(r=.029, \alpha \leq .05)$. The null hypothesis was rejected, and the research hypothesis was accepted. Using Cohen's convention (1988) for describing the magnitude of a relationship, researchers found a small effect size between the 2012 State Fair Equine Skillathon participants' years of participation the State Fair Equine Skillathon and their fundamental equine knowledge. Therefore, it can be concluded that as a participants' years of participation in the State Fair Equine Skillathon increases, his or her fundamental equine knowledge increases. 
Table 12

Association Between Years of Participation in the State Fair Equine Skillathon and Fundamental Equine Knowledge

\begin{tabular}{ll}
\hline & Value \\
\hline Pearson's $r$ & $.029 *$ \\
\hline$* \alpha \leq .05$ &
\end{tabular}




\section{CHAPTER 5}

\section{Summary, Conclusions, and Recommendations}

\section{Purpose of the Study}

This study was designed to determine West Virginia 4-H Horse program participants' equine knowledge. The focus of this study was the fundamental equine knowledge specifically related to horse breed identification, conformation, body and hoof parts, as well as feed identification that West Virginia junior and senior 4-H members who participated in the Equine Skillathon at the 2012 West Virginia State Fair possessed.

\section{Research Questions and Hypotheses}

The objectives of the study are reflected in the following research questions:

1. What are the 2012 State Fair Equine Skillathon participants' knowledge of breeds of horses?

2. What are the 2012 State Fair Equine Skillathon participants' knowledge of the body parts of a horse?

3. What are the 2012 State Fair Equine Skillathon participants' knowledge of conformational faults and abnormalities?

4. What are the 2012 State Fair Equine Skillathon participants' knowledge of the parts of a horse's hoof?

5. What are the 2012 State Fair Equine Skillathon participants' knowledge of feed types and ingredients?

6. Is there an association between members' years of 4-H participation and their fundamental equine knowledge? 
7. Is there an association between members' years of participation in the 4-H Horse Project and their fundamental equine knowledge?

8. Is there an association between a 4-H member having shown at a County 4- $\mathrm{H}$ Horse Show and their fundamental equine knowledge?

9. Is there an association between a 4-H member having participated in the Equine Skillathon at the West Virginia State Fair and their fundamental equine knowledge?

The following hypotheses were used:

Null 1: There was no association between the 2012 State Fair Equine Skillathon participants' years of participation in 4-H and their fundamental equine knowledge. Research 1: There was an association between the 2012 State Fair Equine Skillathon participants' years of participation in 4-H and their fundamental equine knowledge. Null 2: There was no association between the 2012 State Fair Equine Skillathon participants' years of participation in the 4-H Horse project and their fundamental equine knowledge.

Research 2: There was an association between the 2012 State Fair Equine Skillathon participants' years of participation in the 4-H Horse project and their fundamental equine knowledge.

Null 3: There was no association between the 2012 State Fair Equine Skillathon participants' years of participation in a County 4-H Horse Show and their fundamental equine knowledge. 
Research 3: There was an association between the 2012 State Fair Equine Skillathon participants' years of participation in a County 4-H Horse Show and their fundamental equine knowledge.

Null 4: There was no association between the 2012 State Fair Equine Skillathon participants' years of participation in the State Fair Junior Horse and Pony Show and their fundamental equine knowledge.

Research 4: There was an association between the 2012 State Fair Equine Skillathon participants' years of participation in the State Fair Junior Horse and Pony Show and their fundamental equine knowledge.

Null 5: There was no association between the 2012 State Fair Equine Skillathon participants' years of participation in the State Fair Equine Skillathon and their fundamental equine knowledge.

Research 5: There was an association between the 2012 State Equine Skillathon participants' years of participation in the State Fair Equine Skillathon and their fundamental equine knowledge.

\section{Summary}

This study was conducted to assess the fundamental knowledge of junior and senior 4-H members who participated in the Equine Skillathon at the 2012 West Virginia State Fair. Twenty-eight 4-H members participated in the 2012 State Fair Equine Skillathon, and their score sheets were analyzed for the purpose of this study. All the 4-H members were tested on breed identification, conformation, body and hoof parts, and feed identification. The senior 4-H members also answered five additional knowledge questions. 
According to Blalock and Strieter (2007), a skillathon can be used to measure 4-H Horse project participants' knowledge of their project. Junior and senior 4-H members were equally represented in this study. West Virginia consists of 55 counties; only 10 counties were represented in this study. A majority of the $4-\mathrm{H}$ members in this study had participated in a County 4-H Horse Show, the West Virginia State Fair Junior Horse and Pony Show, and/or the West Virginia State Fair Equine Skillathon.

The mean scores for breed identification for junior members $(\mathrm{M}=4.0)$ and seniors $(M=4.64)$ showed no difference between the scores of the junior and senior 4-H members Senior members had slightly higher mean scores $(\mathrm{M}=4.36)$ for conformation than junior members $(\mathrm{M}=2.36)$. There were no differences between the scores of junior $(\mathrm{M}=2.93)$ 4-H members and senior (3.71) 4-H members for hoof parts.

The mean score for body parts was 2.64 points for junior members and 3.14 points for senior members. The total mean score was 2.89 points out of 5.00. This category had the lowest mean score of the five categories.

There was no difference between the junior $(\mathrm{M}=3.14)$ and senior $(\mathrm{M}=3.71)$ members' scores nor the total mean score in feed identification. The senior members scored less than $50 \%$ correct on the multiple choice questions. Although a majority of the participants had participated in various horse shows and events, their equine knowledge was limited.

There was an association between years of participation in the 4-H Horse project, a County 4-H Horse Show, the State Fair Junior Horse and Pony Show, and the State Fair Equine Skillathon with the participants' level of fundamental equine knowledge, so as the years of participation is this events increase, the participants' knowledge level also 
increases. However, years of participation in 4-H did not have a relationship with the participants' fundamental equine knowledge.

\section{Conclusions}

Based on the participants' scores from the Equine Skillathon at the 2012 West Virginia State Fair, one could conclude that 4-H members do not possess as much fundamental equine knowledge as might be expected. Years of participation in the 4-H Horse project, a County 4-H Horse Show, the State Fair Junior Horse and Pony Show, and the State Fair Equine Skillathon does play a role in the amount of knowledge a member may possess. However, the scores from the 2012 State Fair Equine Skillathon reflect that both junior and senior 4-H members possess limited fundamental equine knowledge in the areas of breed identification, conformation, body and hoof parts, and feed identification.

It is essential that 4-H members with horse projects know and understand these areas of fundamental equine knowledge. Therefore, the researcher concludes that the 4-H members who participated in the Equine Skillathon at the 2012 West Virginia State Fair need to work on improving fundamental equine knowledge in the areas of breed identification, conformation, body and hoof parts, and feed identification. Emphasis needs to be placed on the importance of project knowledge development by 4-H youth and its relationship to showing and competition. Previous studies have shown that youth possess stronger skills in showmanship techniques and on fundamental project knowledge as shown in various competitions. 


\section{Recommendations}

The researcher offers the following recommendations based on the results of the study:

1. It is recommended that 4-H leaders and parents continue to work with 4-H members to increase their fundamental equine knowledge in the areas of breed identification, conformation, body and hoof parts, and feed identification through study of their 4-H Project Books and completion of their 4-H Horse Record Guide.

2. It is recommended that 4-H Leaders and Extension professionals stress project knowledge skills, as well as life skills development among 4-H members.

3. It is recommended that County Extension personnel and local 4-H club leaders conduct "mock" skillathons or quiz bowls to encourage project knowledge development.

4. Emphasis needs to be placed on the importance of project knowledge development by $4-\mathrm{H}$ youth and its relationship to showing and competition.

5. It is recommended that additional research be conducted on a larger scale in West Virginia and other states to determine project knowledge of 4-H members. 


\section{REFERENCES}

Anderson, K. P., \& Karr-Lilienthal, L. (2011). Influence of 4-H horse project involvement on development of life skills. Journal of Extension, 49(5). Retrieved from http://www.joe.org/joe/2011 loctober/iw2.php

Barker, B. S. (2007). Stakeholders' input on 4-H science and technology program areas: An exploratory study. Journal of Extension, 45(2). Retrieved from http://www.joe.org/joe/2007april/rb6.php

Beck, C. H., Rayfield, J., Flowers, J., \& Jones, D. (2010). Assessing ground safety knowledge of North Carolina 4-H horse program participants. Journal of Extension, 48(3). Retrieved from http://www.joe.org/joe/2010june/pdf/JOE_v48_3rb5.pdf

Blalock, L. B., \& Strieter, L. (2007). The skillathon: Program evaluation can be fun! Journal of Extension, 45(3). Retrieved from http://www.joe.org/joe/2007june/tt3p.shtml

Boleman, C. T., Cummings, S. R., \& Briers, G. E. (2004). Parents' perceptions of life skills gained by youth participating in the 4-H beef project. Journal of Extension, 42(5). Retrieved from http://www.joe.org/joe/2004october/rb6.php

Boyd, B. L., Herring, D. R., \& Briers, G. E. (1992). Developing life skills in youth. Journal of Extension, 30(4). Retrieved from http://www.joe.org/joe/1992winter/a4.php

Cohen, J. (1988). Statistical power analysis for the behavioral sciences ( $2^{\text {nd }}$ ed.). Hillsdale, NJ: Lawrence Erlbaum Associates. 
Cole, D. L. (2005). Horses and youth (h.a.y.): A not-so-typical approach to at-risk programming. Journal of Extension, 43(3). Retrieved from http://www.joe.org/joe/2005june/rb4p.shtml

Dewey, J. (1938). Experience and education. New York: The Macmillian Company. Enfield, R. P. (2001). Connections between 4-H and John Dewey's Philosophy of Education. FOCUS. Davis: 4-H Center for Youth Development, University of California, Winter.

Fitzpatrick, C., Gagne, K. H., Jones, R., Lobley, J., \& Phelps, L. (2005). Life skills development in youth: Impact research in action. Journal of Extension, 43(3). Retrieved from http://www.joe.org/joe/2005june/rblp.shtml

Gamon, J., \& Dehegedus-Hetzel, O. P. (1994). Swine project skill development. Journal of Extension, 32(1). Retrieved from http://www.joe.org/joe/1994june/rb5.php

Horton, R. L., Hutchison, S., Barkman, S. J., Machtmes, K., \& Myers, H. (1999). Developing experientially based 4-H curriculum materials. Columbus, Ohio: Ohio State University Extension Publications.

Horton, R. L., \& Konen, J. (1997). 4-H classroom science programs enriching the learning environment. Journal of Extension, 35(6). Retrieved from http://www.joe.org/joe/1997december/a1.php

ISU Extension. (1989). Iowa 4-H teaches life skills (4-H 4A). Ames, IA: Extension Publications

Kolb, D. A. (1984). Experiential learning: Experience as the source of learning and development. New Jersey: Prentice Hall. 
McArthur, C., Shields, C. E., \& Zurcher, T. D. (1987). The experiential learning cycle (4-H Program handout). St. Paul: University of Minnesota Extension Service.

McKee, R. K., Talbert, B. A., \& Barkman, S. J. (2002). The challenges associated with change in 4-H/youth development. Journal of Extension, 40(2). Retrieved from http://www.joe.org/joe/2002april/a5.html

Mincemoyer, C. C., \& Corbin, M. (2001). Computer-mediated needs assessment to identify 4-H youth curriculum needs. Journal of Extension, 39(5). Retrieved from http://www.joe.org/joe/2001october/rb7.html

Morris, J. C. (1996). Self-perceived youth leadership life-skills development among Iowa 4-H members. Unpublished doctoral dissertation, Iowa State University, Ames.

Nadeau, J., Alger, E. C., \& Hoagland, T. (2007). Longitudinal study of the general knowledge of 4-H horse members. Journal of Extension, 45(5). Retrieved from http://www.joe.org/joe/2007october/rb6.php

Nadeau, J., Alger, E. C., Hoagland, T., \& Chameroy, K. (2004). Use of a randomized, categorized exam to determine horse knowledge of 4-H horse show participants. Journal of Extension, 42(3). Retrieved from http://www.joe.org/joe/2004june/rb5.php

National 4-H Council. (2012). Who we are. Retrieved from http://www.4-h.org/about/youth-development-organization

Ohio 4-H Youth Development. (2012). Ohio 4-h youth development: Horse learning lab kit. Retrieved from http://www.ohio4h.org/project-books-and-resources/learning-lab-kits/horse 
Pfeiffer, J. W., \& Jones, J. E., Eds. (1985). Reference guide to handbooks and manuals (revised). San Diego: University Associates Publishers.

Plaugher, G., Workman, D. J., Linger, E., Schuller, C. R., \& Woloshuk, J. M. (2006). 4-H horse record guide. Morgantown: West Virginia University Extension Service.

Radhakrishna, R. B., \& Sinasky, M. (2005). 4-H experiences contributing to leadership and personal development of 4-H alumni. Journal of Extension, 43(6). Retrieved from http://www.joe.org/joe/2005december/rb2.php/php

Richardson, J. G. (1994). Learning best through experience. Journal of Extension, 32(2).

Robinson, J. P., Shaver, P. R., \& Wrightsman, L. S. (1991). Criteria for scale selection and evaluation. In J. P. Robinson, P. R. Shaver, \& L. S. Wrightsman (Eds.). Measures of personality and social psychological attitudes (pp. 1-16). New York: Academic Press.

Rusk, C. P., Martin, C. A., Talbert, B. A., \& Balschweid, M. A. (2002). Attributes of Indiana's 4-H livestock judging program. Journal of Extension, 40(2). Retrieved from http://www.joe.org/joe/2002april/rb5.php

Rusk, C. P., Summerlot-Early, J. M., Machtmes, K. L., Talbert, B. A., \& Balschweid, M. A. (2003). The impact of raising and exhibiting selected 4-H livestock projects on the development of life and project skills. Journal of Agricultural Education, 44(3). Retrieved from http://www.jae-online.org/attachments/article/337/44-03-01.pdf

Sawer, B. J. (1987). What 4-H members learn in animal science projects. Corvallis: Oregon State University Extension Service Department of 4-H Youth Development. 
Schlink, K. (2000). Addressing educational needs of youth in today's society. Journal of Extension, (38)4. Retrieved from http://www.joe.org/joe/2000august/comm1.php

Seevers, B., \& Dormody, T. J. (1994). Predicting youth leadership skills development among senior 4-H members: A tri-state study. Journal of Agricultural Education, 35(3), 64-69.

Shurson, J. C., \& Lattner, C. L. (1991). Beyond livestock contests. Journal of Extension, 29(4). Retrieved from http://www.joe.org/joe/1991winter/rb5.php

Smith, C. E., Swinker, A. M., Comerford, P. M., Radhakrishna, R. B., \& Hoover, T. S. (2006). Horsemanship and life skills of youth in horse programs. The Professional Animal Scientist, 22(1), 89-93. Retrieved from

http://pas.fass.org/content/22/1/89.full.pdf

Smith, M. K. (1997). John Dewey. Retrieved from http://www.infed.org/thinkers/et-dewey.htm

Spike, P. W. (1997). Nontraditional knowledge-based dairy youth activities and events. Journal of Dairy Science, 80(8), 1891-1894. doi:

http://dx.doi.org/10.3168/jds.S0022-0302(97)76127-7

The State Fair of West Virginia Exhibitors' Guide. (2012). Retrieved from statefairofwv.com/files/2012/05/Dept.-F-Junior-Show.pdf

VanWinkle, R., Davis, W., Skubinna, T., \& Larwood, L. (2005). Active teaching-active learning: Teaching techniques and tools. Corvallis: Oregon State University Extension Service. Retrieved from http://ir.library.oregonstate.edu/xmlui/bitstream/handle/1957/20957/4h02591.pdf?sequence $=1$ 
Ward, C. K. (1996). Life skill development related to participation in 4-H animal science projects. Journal of Extension, 34(2). Retrieved from http://www.joe.org/joe/1996april/rb2.php

West Virginia Guide to 4-H Projects. (2012). Morgantown: West Virginia University Extension Service. Retrieved from http://4-hyd.ext.wvu.edu/r/download/139504

Woloshuk, J. M., Brown, G., \& Wagaman, G. D. (1999). 4-H projects: Is completion important? Journal of Extension, 37(5). Retrieved from http://www.joe.org/joe/1999october/rb5.html 
APPENDICES 
APPENDIX A

2012 State 4-H Equine Skillathon 
1. Parts of a Horse:
a. Stifle
b. Pastern
c. Throat Latch
d. Point of Shoulder
e. Back

2. Parts of the Hoof
a. Sole
b. White line
c. Heel bulbs
d. Frog
e. Hoof wall

3. Breeds
a. Quarter Horse
b. Arabian
c. American Saddlebred
d. Tennessee Walking Horse
e. Thoroughbred
f. Paint
g. Palomino

4. Conformation (Front view)
a. Base narrow
b. Ideal
c. Bow legged
d. Pigeon toed
e. Knock kneed

5. Feeds
a. $\# 2=$ Whole grain oats
b. $\# 7=$ Whole grain wheat
c. $\# 9=$ Trace mineral salt in salt
d. $\# 6=$ Dicalcium Phosphate
e. $\# 1=$ Dehydrated Alfalfa Meal Pellets

6. Seniors 5 questions plus 4-H involvement questions 
APPENDIX B

2012 State 4-H Equine Skillathon Key 


\section{West Virginia State Fair \\ Senior Equine Skill-a-thon \\ KEY}

Name:

County:

Breeds:

Conformation:
Total:

Body Parts:

Feeds:

\section{Hoof Parts:}

1. Hot horses or horses that have been deprived of water should not be given large quantities of water at one time, because what 2 conditions may occur?
a) Colic and founder
c) Founder and ring bone
b) Colic and wind puffs
d) Bog spavin and bone spavin

2. What is the term for the total protein content present in a given feed?
a) Protein supplement
c) Protein allowance
b) Total digestible protein
d) Crude protein

3. Hay can be a fire hazard when it is
a) $2 \%-5 \%$
c) $10 \%-12 \%$
b) $15 \%-20 \%$
d) $30 \%-40 \%$ moisture.

4. What is the average temperature of a horse?
a) 94.2
c) 98.6
b) 100.5
d) 103.2

5. A horse has how many knees?
a) None
c) One
b) Two
d) Four

\section{TOTAL}

Please respond to the following questions (enter number of years or circle yes or no) How many years have you been in $4-\mathrm{H}$ ?

How many years have you taken the 4-H Horse project?

Have you shown at a County 4-H Horse Show? Yes or No? If yes, how many years?

Have you shown at the State Fair Jr. Horse and Pony Show? Yes or No? How many years?

Have you participated in the State Fair 4-H Equine Skillathon? Yes or No? How many years? 


\section{APPENDIX C}

2012 State 4-H Equine Junior Skillathon 


\section{West Virginia State Fair Junior Equine Skill-a-thon}

Name:

County:

Breeds:

Conformation:

Hoof Parts
Body Parts:

Feeds

\section{Total:}

\section{Please respond to the following questions (enter number of years OR circle yes or no)}

How many years have you been in $4-\mathrm{H}$ ?

How many years have you taken the 4-H Horse project?

Have you shown at a County 4-H Horse Show? Yes No (Circle one)

If yes, how many years?

Have you shown at the State Fair Jr. Horse and Pony Show? Yes No (Circle one) If yes, how many years?

Have you participated in the State Fair 4-H Equine Skillathon? Yes No (Circle one) If yes, how many years? 
VITA

Kolby Denae Wyant

\section{Education:}

West Virginia University

January 2012 - May 2013

Davis College of Agriculture, Natural Resources, and Design

Morgantown, West Virginia

Master of Science

Major: Agricultural and Extension Education

Middle Tennessee State University

May 2010 - December 2011

College of Basic and Applied Sciences

Murfreesboro, Tennessee

Bachelor of Science

Major: Animal Science, Horse Science concentration

Minor: Biology

Honors: Cum Laude

Potomac State College of West Virginia University

August 2008 - May 2010

Keyser, West Virginia

Associate of Applied Science

Major: Equine Production and Management

Associate of Arts

Major: Animal Science

Field Experience:

Equine Reproduction Concepts, LLC

June 2010 - July 2010

Amissville, Virginia

Extern

5 week externship/internship program 